\title{
Characterization and typology of goat production systems in Algeria based on producers survey
}

\author{
Nadjet Amina Ouchene-Khelifi ${ }^{*}$, Nassim Ouchene ${ }^{1}$ and Mohamed Lafri ${ }^{1,2}$
}

\begin{abstract}
Background: Goats, often associated with sheep, are a vital part of the national economy in many countries around the world, and goat farming contributes significantly to the family economy, sustainable livelihoods and poverty reduction. In order to study the goat farming system in Algeria, this study, which started between September 2012 and June 2015, involved 141 farms in 104 villages and 21 wilayas in Algeria.

Results: The results showed that $99.29 \%$ of the goats producers were male, most of which (74.47\%) were not the owners of the animals. Goat farming represents a main activity for only $18.44 \%$ of the farmers surveyed. They are generally found in small numbers often associated with a large sheep herd (78.72\%). Of the 141 farms visited, 50.35\% use a sedentary farming system, $17.71 \%$ practice seasonal transhumance during the dry season (May to October), and $31.91 \%$ are semi-sedentary. However, it is worth noting that females (85.82\%) are often more numerous than males $(14.18 \%)$ in the herd. The farm that generally constitutes the shelter is reduced in most cases to a simple pen, without a roof, inside which the animals are enclosed and whose space is delimited by a metal or wooden fence. Hygiene is in the majority of cases poor (57.45\%). Most of the farms (78.01\%) do not contain goats of the same breed, and crossbreeding is generally not controlled (78.72\%) and is very rarely done with bucks of the same breed (14.89\%). Most breeders (92.20\%) largely neglect the health of their goats compared to sheep.

Conclusion: Finally, the Algerian goat seems to be largely neglected and considered as a secondary species associated with sheep. For this reason, it is mandatory to give more importance to this species. The Algerian government must carry out activities related to the conservation and improvement of breeding systems through the development of breeding programs and ensure the sustainable management of ecosystems used for food production.
\end{abstract}

Keywords: Livestock, Herd, Breeding, Farming system

\section{Background}

Goat farming is a vital component of the national economy in many countries, particularly in the Mediterranean and Middle East regions (Selvaggi and Tufarelli 2012; Selvaggi et al. 2014). The economic and social role played by goat farming is increasingly recognized. The economic and social role played by goat farming is increasingly

\footnotetext{
*Correspondence: khelifinaa@gmail.com

${ }^{1}$ Veterinary Sciences Institute, Saad Dahlab University Blida 1, BP 270,

Road of Soumaa, 09000 Blida, Algeria

Full list of author information is available at the end of the article
}

recognized, as it contributes strongly to the family economy, sustainable livelihoods and poverty reduction (Yandia 2012; Gnanda et al. 2016). It is able to provide high-quality products in a variety of climatic conditions, being resistant to extreme and capricious environments (Selvaggi and Tufarelli 2012; Selvaggi et al. 2014).

According to the FAO (Food and Agriculture Organization), the world goat population is estimated at 1 045915764 head in 2018, of which the African continent accounts for $41.88 \%$ (FAOSTAT 2018). Contrary to other regions of the world where goats are not reared for their meat, which is little appreciated, goat meat is highly 
appreciated and consumed by the majority of the population in Africa (Gnanda et al. 2016; Tchouamo et al. 2005).

The production of goat milk and meat is subject to several constraints, particularly those related to the seasonality of reproduction, which results in an irregular supply (Agreste 2016).

In Algeria, the number of goats was estimated at 4.9 million in 2018 (FAOSTAT 2018).

The local goat populations are mainly found in difficult regions (mountains, forests, steppes and the Sahara) (Ouchene-Khelifi et al. 2015). Since the 1970s, several goat breeding development programs have been implemented in mountainous areas in Algeria, and since 2008, dairy goat breeding has benefited from policies of milk production subsidies initially intended for dairy cattle farms (Sahli 2010).

However, the information available on goat farming in Algeria is very limited and the bibliographical data are very vague and insufficient in relation to sheep and cattle. In this context, this study provides a relevant view of current farming practices in 21 wilayas in Algeria, provides a large amount of information on traditional goat production systems in rural areas and thus identifies possible risk factors weighing on the genetic diversity of the Algerian goat resource.

\section{Methods}

\section{Areas of study}

Our study was initiated between September 2012 and June 2015. The regions concerned by the study include the cradle of goat breeds where goats show a higher concentration.

The study involved 141 farms spread over 104 villages and 21 wilayas (Fig. 1).

The study area is divided by two major mountain ranges, the Tellian Atlas in the north and the Saharan Atlas in the south, which divides the study area into three ecotypes and is distinguished by topography, altitude, soil type, vegetation diversity and climatic conditions.

In the north, the Tellian system consists of a succession of mountain massifs, of medium to high altitude (Djurdjura with an altitude of $2308 \mathrm{~m}$ ) and depressions represented by the low plains of Oran, Chlef and Mitidja (Hadjiat 1997; Nedjraoui 2006; Benslimane et al. 2008). Forests, scrub and matorrals are the dominant plant formations. Rainfall varies from 450 to $1500 \mathrm{~mm} /$ year. The climate along the coast is cooled by the presence of the sea. The average minimum temperature of the coldest month is between $0{ }^{\circ} \mathrm{C}$ and $9{ }^{\circ} \mathrm{C}$, and the average maximum temperature of the hottest month varies from $28^{\circ} \mathrm{C}$ to $31^{\circ} \mathrm{C}$ (Nedjraoui 2006).

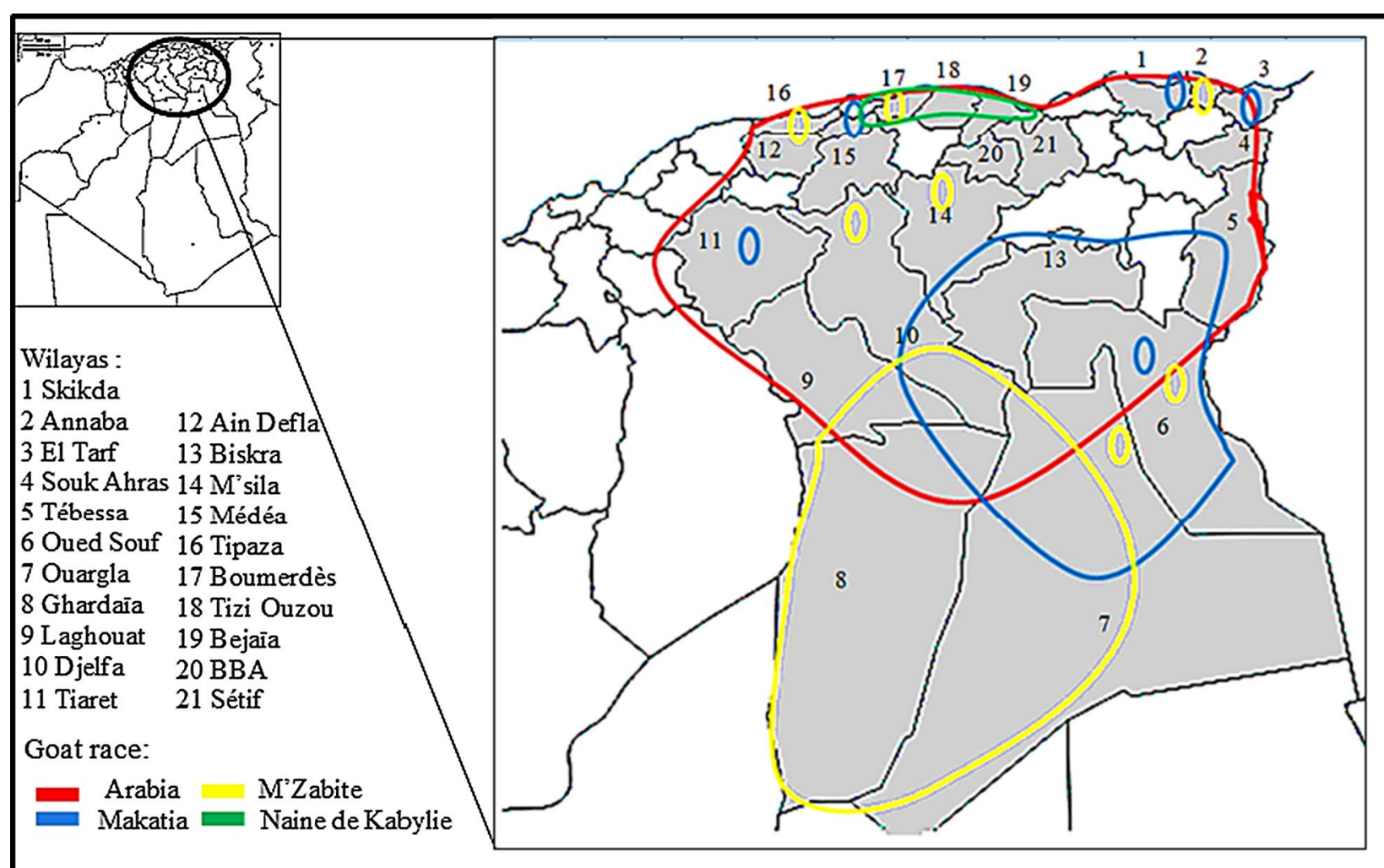

Fig. 1 Presentations of the study regions and the range of the different goat populations 
In the intermediate zone (located between the Tell Atlas in the north and the Saharan Atlas in the south), the high steppe plains form an ecosystem characterized by various heterogeneous plant formations of herbaceous and shrubby plants, resistant to drought and capable of coping with poor and scarce soils. The steppe is dominated by esparto (Stipa tenacissima), esparto (Lygeumspartum), Artemisia mugwort (Artemisia herba alba) representing an interesting and pastoral value (Teucrium la chardonianum) from Hamada located in the regs (Nedjraoui 2006). The altitude varies from 400 to $1200 \mathrm{~m}$. The climate is semi-arid to arid and is characterized by low rainfall (100-450 $\mathrm{mm}$ per year) and high thermal amplitudes (BNEDER 2006).

In the south, the Sahara is a desert with some oases. It consists of plains, contrasting with the Hoggar which peaks at $3000 \mathrm{~m}$ (Nedjraoui 2006; Benslimane et al. 2008). Vegetation is contracted and localized in the wadi beds. It is a hygrophilic and psamophilic vegetation that is highly adapted to xeric conditions and has a very high rate of endemism. Pastures based on grass species such as Stipagrostis and Panicum turgidum and forage shrubs such as the numerous acacias can be found (Nedjraoui 2006). Rainfall is scarce $(50 \mathrm{~mm} /$ year recorded in the M'Zab region), and the temperature range is very high ( $49^{\circ} \mathrm{C}$ during the day to less than $10^{\circ} \mathrm{C}$ at night) (MADR 2004).

\section{Sampling and data collection}

A survey form was designed with questions designed to elicit appropriate responses to meet the research objective. The questions were identical for all the farmers interviewed to ensure that variations in responses were due to individual differences rather than to the interviewers, thus seeking to identify and assess the main management systems adopted.

The questionnaire, which included both qualitative and quantitative information, is divided into the following sections:

- General information: farm code, location, GPS position, profile of the respondent (age and intellectual level).

- Profile of the farm (private, state, cooperative), area.

- Size of the goat herd in detail.

- Mode and type of breeding.

- Breeds (or population) of goats, main criteria for recognition and the criteria assessed.

- Condition of livestock buildings.

- Feeding and watering.

- Reproduction and renewal.

- Prophylactic and sanitary plan.

\section{Description of the sample}

Goat farms in most cases are associated with sheep. They produced either goat's milk or animals for slaughter. In the majority of cases goats were seen as a saving that allowed urgent needs (e.g., health care, illness, ceremonies, schooling, marriage) to be met through sale. The labor force was family based in most of the farms.

\section{Results}

The goatherd in most cases $(74.47 \%)$ is not the owner of the animals (Table 1). According to some statements, the goatherd is simply an employee receiving a monthly salary of 30,000 to 40,000 DA (Algerian Dinar). His food is generally based on milk, cakes and "Robe" (jam made from dates and butter).

Almost all the people interviewed were men (99.29\%), with an intellectual level that varies from a very low level (35.46\%), without any scientific knowledge, to a very high level where he is interested in the smallest details as the case of the breeder of El Atteuf in Ghardaïa and that of Iourassen in Bejaia (1.42\%). In total, $70.92 \%$ of the breeders were between 35 and 50 years old (Table 1).

Goat breeding represents a main activity for only $18.44 \%$ of the breeders interviewed. They are generally found in small numbers often associated with a large sheep herd (78.72\%) (Table 2). The number of goats present represents about $10 \%$ of the total flock. As a result, they are marginalized secondary animals to sheep for most farmers (78.01\%) (Table 2).

In general, there are no specialized goat farms, except for some $(7.09 \%)$ that have been able to preserve the breed in the region, for example:

\section{Table 1 Social profile analysis of producers}

\begin{tabular}{lllc}
\hline Variables & & N & \% \\
\hline $\begin{array}{l}\text { Profile of the respondent } \\
\text { owner of the farm }\end{array}$ & Owner of the farm & 36 & 25.5 \\
& Worker & 100 & 70.9 \\
& Technician & 5 & 3.55 \\
Gender & Man & 140 & 99.3 \\
& Woman & 2 & 1.42 \\
Age & <35 years old & 13 & 9.22 \\
& 35-50 years old & 100 & 70.9 \\
& $>50$ years old & 28 & 19.9 \\
Intellectuel level & Illiterate & 50 & 35.5 \\
& Primary & 50 & 35.5 \\
& Medium & 20 & 14.2 \\
& High School & 19 & 13.5 \\
& Academic & 2 & 1.42 \\
\hline
\end{tabular}

$\mathrm{N}$ : number of answers in the questionnaire

$\%$ : percentage of answers in the questionnaire 
Table 2 Characteristics of goat rearing in the different study areas

\begin{tabular}{|c|c|c|c|}
\hline Variables & & $\mathrm{N}$ & $\%$ \\
\hline \multirow[t]{3}{*}{ Profile of the farm } & Private & 134 & 95.04 \\
\hline & Cooperative & 5 & 3.55 \\
\hline & State & 2 & 1.42 \\
\hline \multirow[t]{3}{*}{ Goat herd size } & Reduced $(<100$ head) & 135 & 95.74 \\
\hline & Medium (100-300) & 5 & 3.55 \\
\hline & Important (300-1000) & 1 & 0.71 \\
\hline \multirow{3}{*}{ Breeding method } & Semi-sedentary & 45 & 31.91 \\
\hline & Sedentary & 71 & 50.35 \\
\hline & Transhumant & 25 & 17.73 \\
\hline \multirow[t]{4}{*}{ Livestock component } & goat & 10 & 7.09 \\
\hline & Sheep and goat & 111 & 78.72 \\
\hline & Goat and Cattle & 10 & 7.09 \\
\hline & Sheep, goat and cattle & 20 & 14.18 \\
\hline \multirow[t]{2}{*}{ Gender Type } & Male & 20 & 14.18 \\
\hline & Female & 121 & 85.82 \\
\hline \multirow[t]{3}{*}{ The goat house } & Classic goat's cheese (Z'riba) & 75 & 53.19 \\
\hline & Covered goat's milk products & 30 & 21.28 \\
\hline & Semi-open goat house & 36 & 25.53 \\
\hline \multirow[t]{2}{*}{ Separation into batches } & Yes & 35 & 24.82 \\
\hline & No & 106 & 75.18 \\
\hline \multirow[t]{3}{*}{ Hygiene of the premises } & Good & 10 & 7.09 \\
\hline & Intermediary & 50 & 35.46 \\
\hline & Dirty & 81 & 57.45 \\
\hline \multirow{3}{*}{$\begin{array}{l}\text { Importance of the goat } \\
\text { for the breeder }\end{array}$} & Main & 26 & 18.44 \\
\hline & Secondary & 30 & 21.28 \\
\hline & Marginale & 85 & 60.28 \\
\hline
\end{tabular}

$\mathrm{N}$ : number of answers in the questionnaire

$\%$ : percentage of answers in the questionnaire

- Arabia: in some farms in Laghouat and Tiaret (Ksar chellala).

- The M'Zabite: in a large breeding farm (more than 300 goats at different ages) in Ghardaïa.

- La Naine de Kabylie: at a breeder in the wilaya of Bejaia (Iouressen) for its meat.

- The Makatia: breeders in Ouargla and El Oued have been able to preserve this breed.

On the other hand, in some regions, particularly in TiziOuzou, we observed several breeders who specialized in the breeding of the Saanen for its great capacity to produce milk. Some of them have even been able to build and operate goat's milk and cheese production units.

In addition, in Biskra, the ITDAS center (Technical Institute for the Development of Saharan Agriculture) has developed a modern breeding farm containing the Alpine breed solely for the purpose of setting up a small cheese dairy unit.
Goat rearing in the study regions is characterized by three different systems (Table 2):

Sedentary system, the animals do not move all year round; they are either in the goat house all the time and it is up to the farmer to bring them mown grass, and sometimes the animals travel short distances in the surrounding land.

Semi-sedentary system, with the use of one or two seasonal pastures located at a distance of about $50 \mathrm{~km}$ from the main breeding areas;

Transhumant system, with the use of pastures in general in the Saharan regions during the winter and in the northern zone during the summer.

Our results show that $50.35 \%$ are sedentary, $17.71 \%$ practice seasonal transhumance during the dry season (May to October), and $31.91 \%$ are semi-sedentary (Table 2).

The majority $(95.04 \%)$ of the farms visited were privately owned. However, it is useful to note that females $(85.82 \%)$ are often more numerous than males (14.18\%) (Table 2).

In most cases, the farm that generally constitutes the shelter is reduced to a simple pen, without a roof, inside which the animals are confined and whose space is delimited by a metal or wooden fence. In $53.19 \%$ of the cases (Table 2), the goat house is of the conventional type (Table 2).

Some farmers $(24.82 \%)$ allocate the animals according to their age and physiological condition. However, it is useful to note that in the wilaya of El Oued, herders group their animals together in an area called "el-ghoutt," by digging a large area surrounded by dunes and palm trees (Table 2).

Hygiene in the goat herds is in most cases poor $(57.45 \%)$ and leaves much to be desired. The farmer rarely scrapes the soil (Table 2 ).

With regard to farming and livestock management systems, farmers adopt two different systems: the extensive system or the semi-intensive system.

Livestock farmers are obliged to rent several plots of land in order to meet the feed requirements of their animals. The shepherd sets up his tent in front of the stubble and fallow land he rents out, leaving his family inside the tent, and brings his animals into shelters during the period of excess heat.

In terms of local goat populations and breeds encountered, there are actually four local goat populations and each of them is well adapted to a different ecotype (Fig. 1). The most dominant population is Arabia, with a very wide range, which we found in all the regions visited, but especially in the steppe regions and high plateaux (Tébessa, Souk Ahras, Guelma, Sétif, M’Sila, Djelfa, Laghouat and Tiaret). It is raised for its meat where the 
carcass weighs on average 15 to $20 \mathrm{~kg}$. The average quantity of milk produced is small compared to other local populations and does not exceed one (1) liter per day. It should be noted that this population is also appreciated for the quality and quantity of its hair.

A second population exists, the M'Zabite, which is raised mainly for its milk with an average quantity of 2 to $3 \mathrm{~L}$ of milk per day. It is mainly found in Ghardaïa and Laghouat. It is well adapted to the Saharan regions.

The Makatia, for its part, is located in the south, especially in the wilayas of Ouargla and El Oued. Its milk production reaches 1 to $2 \mathrm{~L}$ per day.

As for the Naine de Kabylie, it is mainly found along the coast, mainly in Bejaia and Tizi Ouzou. It has a very low milk production (less than one liter per day), and the breeders are mainly interested in it for its meat, which is of good quality.

Alpine and Saanen were found in all the regions visited. They are either raised alone or with the local population in the same farm.

It should be noted that crossbreeding was found in all the regions visited.

The goats are fed mainly on pasture for a period of about $8 \mathrm{~h}$ a day. Most often, the shepherd takes his animals out, often accompanied by his dog, at daybreak ( 5 a.m.) and returns home around $10 \mathrm{a} . \mathrm{m}$. to rest and take a nap, thus avoiding the period of the day when the heat is excessive. Around 3 p.m. the breeder returns to the pasture with his herd and goes home at sunset.

Other farmers take their herds out early in the morning each day and do not return until sunset.

A few exceptions can be cited, notably small herds, and some family herds in the south, where the farmer keeps the animals in permanent stalls and brings food to the goat house, which can cause the hooves to grow longer.

In this study, $56.7 \%$ of the herders surveyed reported that their land was rented. In the North, animals are often taken to fallow fields and stubble fields, which can provide them with sufficient feed. On the other hand, the food resources of the herds in the steppe and in the Sahara are made up of several types of vegetation such as esparto (Helfa), mugwort (Chih), esparto (sennagh), gattilier (kherouaa), drinn, acheb and n'djem.

Feed supplementation based on rough crops such as hay $(32.62 \%)$, straw $(39.01 \%)$ and other crop residues including barley $(10.64 \%)$ and maize $(10.64 \%)$ is distributed to animals during periods when grass is unavailable.

However, it is worth noting that supplementation with industrial concentrate feed is rarely used (7.09\%) (Table 3).

It should be noted that in the wilaya of El Oued, herders add a diet based on poor-quality dates or date scraps.
Table 3 Characteristics of the different feeding methods for goats in the different study areas

\begin{tabular}{llcc}
\hline Variables & & N & $\%$ \\
\hline Nature of forage (pasture) & Steppe route & 43 & 30.5 \\
& Saharan route & 34 & 24.11 \\
& Barley in green & 13 & 9.22 \\
& Uncultivated fallow land & 17 & 12.06 \\
& Cereal stubble & 13 & 9.22 \\
& Grass (natural meadow) & 21 & 14.89 \\
Ownership of the plots & Staff & 30 & 21.28 \\
& Tribal & 20 & 14.18 \\
& Rental & 80 & 56.74 \\
& Domaniale & 11 & 7.8 \\
Dietary supplementation & Straw & 55 & 39.01 \\
& Hay & 46 & 32.62 \\
& Barley & 15 & 10.64 \\
& Corn & 15 & 10.64 \\
& Concentrated food (ONAB) & 10 & 7.09 \\
& At will & 100 & 70.92 \\
Drinking water & Rationed & 41 & 29.08 \\
\hline
\end{tabular}

$\mathrm{N}$ : number of answers in the questionnaire

$\%$ : percentage of answers in the questionnaire

The watering of animals takes place after the return of the animals. Water is distributed at will. Farmers generally use well water.

Generally, crossings are not controlled (78.72\%). In fact, crossbreeding is very rarely done with bucks of the same breed (14.89\%) (Table 4). The goats are crossed with bucks of another breed, which results in a crossbred population.

In total, $78.01 \%$ of the farms in the study do not have goats of the same breed (Table 4). In addition, the breeders surveyed stated that they had brought back introduced breeds in order to improve the local population. The Saanen and Alpine for their milk production and the Damascus (shammi) for its milk productivity and ability to sire twins.

On the other hand, some breeders give crucial importance to crossbreeding (21.28\%), where we have reported for example in Laghouat breeders of the Arabia breed who have been preserving the breed for several years and who have Arabia bucks whose weight in some cases exceeds $100 \mathrm{~kg}$ and which are intended solely for breeding.

In total, $70.92 \%$ of the breeders surveyed reported that breeding is carried out by the male permanently present in the herd (Table 4).

The use of the same breeding buck was reported by the majority of breeders $63.83 \%$. Some reported that 
Table 4 Management of goat reproduction in the different study areas

\begin{tabular}{|c|c|c|c|}
\hline Variables & & $\mathbf{N}$ & $\%$ \\
\hline \multirow[t]{5}{*}{ Individuals' reasons for reform } & Age & 40 & 28.37 \\
\hline & Accident & 25 & 17.73 \\
\hline & Infertility & 15 & 10.64 \\
\hline & Pathologies & 40 & 28.37 \\
\hline & Economic & 21 & 14.89 \\
\hline \multirow[t]{3}{*}{ Renewal frequency } & All year round & 60 & 42.55 \\
\hline & Once a year & 35 & 24.82 \\
\hline & twice a year & 46 & 32.62 \\
\hline \multirow[t]{2}{*}{ Crossroads } & Controlled & 30 & 21.28 \\
\hline & Uncontrolled & 111 & 78.72 \\
\hline \multirow[t]{2}{*}{ Livestock Component } & same breed & 31 & 21.99 \\
\hline & several races & 110 & 78.01 \\
\hline \multirow[t]{2}{*}{ The breeding bucks } & Of the same race & 90 & 63.83 \\
\hline & Race is not considered & 51 & 36.17 \\
\hline \multirow[t]{2}{*}{ Renewal of breeding bucks } & Yes & 51 & 36.17 \\
\hline & No & 90 & 63.83 \\
\hline \multirow{2}{*}{$\begin{array}{l}\text { The presence of bucks with the } \\
\text { females in permanent }\end{array}$} & Yes & 100 & 70.92 \\
\hline & No & 41 & 29.08 \\
\hline \multirow[t]{3}{*}{ Straddling } & Once a year & 30 & 21.28 \\
\hline & twice a year & 21 & 14.89 \\
\hline & 3 times every 2 years & 90 & 63.83 \\
\hline
\end{tabular}

$\mathrm{N}$ : number of answers in the questionnaire

$\%$ : percentage of answers in the questionnaire

they lend or rent bucks from a neighbor to encourage new blood (36.17\%) (Table 4).

Mating is almost natural with free riding, with only one buck for every 20 to 30 goats.

The latter is chosen in the majority of cases according to his breeding activity without consideration of the breed.

The goats are generally in concordance with the lambing (between January and March), 3 times in 2 years in general.

The renewal of the herd is done according to different reasons often associated with the age of the animals (28.37\%), accidents, especially of the locomotive type (17.73\%), infertility problems $(10.64 \%)$ and health problems $(28.37 \%)$ or purely economic (14.89\%) (Table 4 ). We can also add that the farmer is obliged to sell most of his livestock in times of drought and rising feed prices.

The frequency of herd renewal varies from one farm to another. In fact, there are those who regularly sell their animals from one market to another in order to earn money (42.55\%), and also those who keep them for a long period of time using males from the same herd for reproduction, which favors the raising of inbreeding levels.
Table 5 Health management in the different goat farms in the different study regions

\begin{tabular}{llrc}
\hline Variables & & N & $\%$ \\
\hline Treatment of goats & No & 130 & 92.2 \\
& Yes & 11 & 7.8 \\
The most common diseases & Parasites & 54 & 38.3 \\
& Infectious Diseases & 40 & 28.37 \\
& Metabolics & 22 & 15.6 \\
& Reproduction & 25 & 17.73 \\
Health monitoring is ensured by & Veterinarian & 44 & 31.21 \\
& Self-medication & 97 & 68.79 \\
\hline
\end{tabular}

$\mathrm{N}$ : number of answers in the questionnaire

$\%$ : percentage of answers in the questionnaire

Most of the breeders report that they use the milk of their goats to feed their children and some of it is sold. The average price of a liter of goat's milk is $100 \mathrm{DA}$. This is a source of money that the farmer earns in addition to the meat produced by the fattened kids and goats.

Respondents also state that the products and income provided by goats are far from negligible:

- The meat: of good protein quality, and lean, making it interesting for people concerned about a low-calorie and hypocholesterolemic diet.

- Milk provides part of the diet for small children and provides very good quality raw milk, curdled milk and fermented milk for the whole family.

- The tanned skins are used as carpets or to make the "chekoua" (a skin used to churn milk) and the "Guerba" (a skin that keeps the water cool in summer, light, insulating and easy to transport).

- Goat hair is used to make tents and ropes.

With regard to health, there is discrimination in animal care. Indeed, farmers (92.20\%) largely neglect the health of their goats compared to sheep. Only a few farmers (7.80\%) treat and vaccinate their animals (Table 5). Preventive antiparasitic treatments and the anti-enterotoxemia vaccine are intended only for sheep. Despite this, goats are considered to be very hardy animals with a low mortality rate compared to sheep (5\% vs. 10 to $15 \%$ ).

Parasitic disorders are the most frequent $38.30 \%$ of the diseases encountered, followed by infectious disorders $28.37 \%$, reproductive disorders $17.73 \%$ and metabolic diseases $15.60 \%$ (Table 5).

Farmers indicate that they treat their animals themselves (68.79\%) and that they seek veterinary care in only $31.21 \%$ of cases (Table 5).

Finally, in the course of our investigation, we noted that several problems constitute an obstacle to goat breeding 
and contribute to the erosion of goat genetic biodiversity in Algeria, in particular:

- The sale of goats at livestock markets (located in the north) where breeders bring their animals back, thus favoring crossbreeding and mixing between breeds. This phenomenon is often encountered among breeders who frequently renew their herds in order to sell them after fattening in neighboring markets. In this way, it can be noted that their farms contain all breeds at the same time, especially if they do not prefer a specific breed.

- Another major problem lies in the unavailability of water and food, especially in the south and during periods of drought when the breeder is forced to sell his livestock to cover his expenses. The intellectual level of the herders should not be neglected, as it influences the management and running of their farms.

- The difficulty of marketing goat meat compared to sheep meat is also a major concern, since Algerians tend to consume more sheep and beef than goat meat.

\section{Discussion}

Goat breeding in Algeria, associated with sheep breeding, is a very important agricultural activity, especially in the most disadvantaged regions where it contributes to the family economy to meet the urgent needs of the farmer.

The predominance of men interviewed in this study is in line with that already observed in Algeria by Laouadi et al. $(2011,2018)$ in Laghouat $(98.11 \%$ and $94.3 \%$, respectively), Kadi et al. (2014) in the mountainous area of Kabylia (86.2\%). The same was also observed in Egypt and Nigeria by Abd-Allah et al. (2019) and IyiolaTunji and Issa (2010), respectively. The average age of the interviewed farmers was 45.6 years, which is consistent with the results of Laouadi et al. (2018), Guilherme et al. (2017) and Abd-Allah et al. (2019).

Indeed, these low results could indicate that young people are not interested in goat rearing and are moving toward the practice of quick and easy income professions such as trade (Laouadi et al. 2018). This is also a consequence of the migration of young people to urban centers in search of better living conditions (Lima and Baiardi 2000). Age of the herders can influence the management of the farm, when comparing the differences in expectations between the young and the elderly. Young people are bold and innovative (Holanda Junior and Campos 2003); however, experience gained with age is also valuable (Alencar 2008).
In the present study, $35.46 \%$ of the farmers surveyed had a very low intellectual level (illiterate), which is lower than the results reported in Algeria by Laouadi et al. (2018) in Laghouat (44.3\%) and Hadbaoui (2013) in M'sila (60\%) and in Brazil by Guilherme et al. (2017) (83.9\%). In addition, $1.42 \%$ of the herders had attended university, a low rate compared to the results reported by Abd-Allah et al. (2019) where 19\% had a university degree. These results would therefore be reflected in the production profile, management techniques and sanitary practices adopted, considering also that the level of education can be directly related to the technical level existing on the farm Costa et al. (2011). Indeed, low literacy is an asset for improving goat-raising strategies, as scientifically qualified communities are more likely to adopt and practice new technologies, which can improve rural development (Abd-Allah et al. 2019). However, people with higher levels of education have a greater ability to understand and assimilate new techniques, and therefore there is an increased likelihood that these new techniques will be adopted by them (Monte and Teixeira 2006). In this study, we found that goat rearing is a secondary and marginal activity in Algeria. This is also consistent with results reported from studies in Brazil (Guilherme et al. (2017), Argentina (Arias and Alonso 2002), Mexico (Pérez et al. 2010; Hernández et al. 2011; Rodríguez et al. 2011), Chile (Mujica et al. 2015), Venezuela (Morantes et al. 2008) and the Dominican Republic (Valerio et al. 2009). Goats are often $(78.01 \%)$ associated with sheep farming. Our results are close to those of Laouadi et al. (2018). This association with other animal species in these rural areas was also reported by Moula et al. (2017), AbdAllah et al. (2019), Sibisi (1979), Guilherme et al. (2017) and Bembridge (1984).

Goats are able to cover long distances, use the least accessible parts (Gaspar et al. 2008), play an important role in herd management and act as guides for the herd on the rangelands by prospecting and attracting the herd to the most favorable grazing areas.

In our study, $50.35 \%$ of the farmers surveyed do not travel with their herds. A higher rate was reported by Laouadi et al. (2018) (63.2\%). However, this practice has a growing trend linked to land privatization and schooling of children (Deleule, 2016). This predominance of extensive grazing has also been reported by Hadbaoui (2013) in the M'sila region (Algeria) and Almeida et al. (2006) in north-eastern Brazil. It differs, however, from the results reported by Guilherme et al. (2017) and Gonçalves et al. (2008) in Brazil where the semi-intensive farming system was predominant.

Goat and sheep herds in the Mediterranean region such as Spain, France, Italy and Greece are raised in 
systems ranging from intensive to extensive (Rancourt et al. 2006).

Indeed, under normal conditions, the extensive system is predominant in livestock farming with limited resources, as is the case for goats and sheep (Guilherme et al. 2017). The practice of sedentarization leads to a weakening of former collective management institutions, leaving room for uncoordinated use of natural resources and land degradation (Rondia 2006), the practice of sedentarization leads to a weakening of former collective management institutions, leaving room for uncoordinated use of natural resources and land degradation.

The results also showed that females (85.82\%) often outnumber males (14.18\%). The same results were observed by Katongole et al. (1996) (69\% females and $31 \%$ males) and Hagan et al. (2012) (29.8\% males and $70.2 \%$ females). This distribution could be due to the orientation of the males toward selling at livestock markets, gifts, sacrifices or slaughter, thus minimizing feeding costs, while the females are preserved and reserved for breeding and milk production and therefore spend a longer time in the herds. Most male animals are therefore preferably fattened for sale. Meat is a quick source of income for owners in need (purchase of agricultural and food inputs, payment of hospital bills, school fees, expenses for funerals, weddings and others) (Hagan et al. 2012; Fajemilehin and Salako 2008; Apori et al. 2011).

Knowledge of the reasons for rearing is a prerequisite for setting operational rearing objectives (Jaitner et al. 2001). The goat can be a source of income throughout the year and contribute to meeting family needs for milk and meat (Ammar et al. 2011; Nassif and El Amiri 2011; Kadi et al. 2014; Abd-Allah et al. 2019). The same finding was recorded in the present study, where the animals raised were appreciated above all for the quality of their meat (66.67\%) and their milk production (10.64\%).

Gopalakrishnan and Lal (1985) reported that goats generally produce more milk than cows from the same amount of nutrients, indicating more efficient feed conversion. However, the low rate of milk production is for either kid feed or domestic consumption.

In $53.19 \%$ of the farms visited, the goat house is of the classic type. Some farmers $(24.82 \%)$ allocate animals according to their age and physiological condition. This rate is relatively low compared to the results reported by Guilherme et al. (2017) where the installations and fences were present in most farms. The problems associated with keeping goats without fencing may be due to the poverty of farmers who cannot afford a fence to avoid them, or perhaps to their low rate of goat ownership.

It was reported that goats cause problems when left to roam around, goats destroy crops. The rooting is also a problem as they can uproot crops. Similar practices have been reported by Kakengi et al. (2000) in Tanzania, Ogebe et al. (2000) in Nigeria and Abd-Allah et al. (2019) in Egypt.

In the present study, $56.7 \%$ of the farmers surveyed reported that their land was rented. This is consistent with the results of Abdu-Allah et al. 2019, which recorded a percentage of $40 \%$.

Feed supplementation based on rough crops such as hay $(32.62 \%)$, straw $(39.01 \%)$ and other crop residues including barley $(10.64 \%)$ and maize (10.64\%) is distributed to animals during periods when grass is unavailable. This is consistent with the results reported by Laouadi et al, (2018) where the practice of feeding fodder crops was common (64.1\% of farmers), with wheat and barley predominating. Animals are grazed on natural pastures close to their farms (84.9\%) and are then supplemented with stored fodder or crop residues.

However, it is worth noting that supplementation with industrial concentrated feed is rarely used by the farmers surveyed (7.09\%). This rate is very close to the result reported by Laouadi et al. (2018) (8.49\%).

According to Guilherme et al. (2017), 76\% of the farmers do not adopt fodder conservation practices. In fact, farmers are not trained in this type of technique to which is added the cost of paid labor in several phases of production. These findings are consistent with those described by Riet-Correa et al. (2013).

In total, $35.46 \%$ of the breeders surveyed report that the choice of introduced individuals is often based on good conformation (live weight, large size) without taking the breed into consideration. This was also reported by Laouadi et al. (2018).

In total, $78.01 \%$ of the farms surveyed did not contain goats of the same breed. In addition, the breeders surveyed stated that they had brought back introduced breeds. This was also recorded by Laouadi et al. (2018). Indeed, a strong presence of exotic breeds indicates the interest of breeders in productive characteristics such as milk production and meat quality. Moreover, the breeders of the region contribute to the evolution and conservation of these breeds according to their objectives (monetary income) and practice uncontrolled crossbreeding with mainly Arabia and other breeds (local or exotic). Moreover, this cohabitation certainly risks leading to uncontrolled crossbreeding, thus causing the loss of the local goat gene pool.

Taking into account the morphobiometric characteristics of the local type goat population (taking into account qualitative and quantitative variables) has made it possible to highlight the consequences of crossing practices affecting local population breeds. Indeed, measures must be put in place to ensure that crossbreeding is carried out while respecting the valuable characteristics of these 
breeds adapted to local conditions by preventing genetic dilution (Ouchene-Khelifi et al. 2015).

Crossbreeding practices allow the loss of genetic integrity of goat breeds to be demonstrated. Indeed, a clear genetic dilution affecting the Algerian goat stock and an overall homogeneity have been demonstrated. In total, $70.92 \%$ of the breeders questioned reported that reproduction is ensured by the male permanently present in the herd. This implies that very young females or females with reproductive problems must be available for mating, which has a negative influence such as damage to body development, in the case of very early reproduction, and the maintenance of unproductive animals, in the case of females with reproductive problems, Guilherme et al. (2017). The use of the same breeding buck was reported by the majority of breeders $63.83 \%$. The same finding was recorded by Laouadi et al. 2018. Indeed, the use of the same billy goat in breeding should increase the level of inbreeding as explained by Kosgey et al. (2006), whereas the selection of replacement animals outside their own herd represents a high risk of loss of the pure breed. The criteria chosen by the respondents for the selection of breeding goats (body conformation and performance of parents) are very important, as they take into account both productivity (prolificity) and marketing aspects (kids with good body conformation from good milk producers and prolific dams will provide more income). Selection criteria may differ according to breed, herd size, production system and marketing opportunities available in the region (Kebede et al. 2012).

In total, $92.20 \%$ of the farmers surveyed largely neglected the health of their goats. This is consistent with the study by Laoudi et al. (2018), which suggests that in $82.1 \%$ of cases herds are irregularly checked by a veterinarian or health technician.

On the other hand, in Brazil, Guilherme et al. (2017) report that $86 \%$ of farms have treated their animals. Parasitic disorders are the most frequent $38.30 \%$ among the diseases encountered. This is in line with the results reported by other authors (Guilherme et al. 2017 (37\%), Abd-Allah et al. (2019), Kasambula et al. 2012 and Waiswa et al. 2006). Farmers indicate that they use veterinarians in only $31.21 \%$ of cases; otherwise, in $68.79 \%$ of cases they treat their animals themselves, a result very similar to that of Laouadi et al. 2018 (67.9\%). According to Laouadi et al. (2018), treatments may include medicinal herbs (10.4\%) and other traditional practices (24.5\%).

\section{Conclusion}

The Algerian goat constitutes a very diverse and important reservoir from which the breeder draws to meet his needs and is composed of four distinct breeds (Arabia, M'zabit, Makatia and Kabyle dwarf) of which Arabia is the most widespread. Despite this very important resource, the Algerian breeder largely neglects the importance of this species where the goat is still marginalized and considered as a secondary species associated with sheep. Reproduction is not under control, and in most cases, the farmer neglects the health of his goats compared to sheep. The farming system is characterized by small structures lacking organization, which has hampered the development of goat farming in Algeria. Incentives are needed to enable farmers to give more importance to goats.

To this end, the Algerian government must carry out activities relating to in situ conservation, including performance recording systems, the development of selection programs (with the creation of artificial insemination centers) and ensure the sustainable management of ecosystems used for food production. Previous development of plans to protect unique animal genetic resources in the event of disease outbreaks or other serious threats. In many cases, such measures can not only reduce the risk of genetic erosion, but also promote the efficient use of existing genetic resources and thus be complementary to the broader development objectives of goat farming.

\section{Abbreviations}

$\mathrm{N}$ : Number of answers in the questionnaire; \%: Percentage of answers in the questionnaire; DA: Algerian dinar; mm: Millimeter; ${ }^{\circ} \mathrm{C}$ : Degree celsius; m: Meter; Kg: Kilogram; l: Liter.

\section{Acknowledgements}

The authors would like to thank the consumers and farmers that supported us.

\section{Authors' contributions}

OKNA, ON conceived and designed the experiments; performed the experiments; analyzed the data; and wrote the paper; OKNA, ON, LM contributed to the paper redaction. All authors have read and approved the final manuscript.

\section{Funding}

This research did not receive any specific grant from funding agencies in the public, commercial or not-for-profit sectors. The authors declared that the research was carried out with their own funds.

\section{Availability of data and material \\ Not applicable.}

\section{Ethics approval and consent to participate}

The manuscript does not contain animal and clinical studies or patient data.

\section{Consent for publication}

Not applicable.

\section{Competing interest}

Authors declare that there are no conflicts of interest.

\section{Author details}

${ }^{1}$ Veterinary Sciences Institute, Saad Dahlab University Blida 1, BP 270, Road of Soumaa, 09000 Blida, Algeria. ${ }^{2}$ Laboratory LBRA, Veterinary Sciences Institute, Saad Dahlab University Blida 1, BP 270, Road of Soumaa, 09000 Blida, Algeria.

Received: 10 June 2020 Accepted: 29 December 2020

Published online: 13 January 2021 


\section{References}

Abd-Allah S, Mohamed MI, Shoukry MM, Salman M, Abd- El Rahman HH (2019) Assessment of the traditional goat production systems in rural areas of the Nile Delta in Egypt. Bull Nat Res Centre 43:114. https://doi. org/10.1186/s42269-019-0153-3

Agreste (2016) Agreste Conjoncture Lait, Agreste Infos rapides - Lait - Février $2016\left(n^{\circ} 02 / 11\right), 7 p$

Alencar SP. (2008) Aspectossocioeconômicos e sanitários dos rebanhoscaprinos e ovinos no sertão de Pernambuco. Pernambuco. 2008. Tese (DoutoradoemCiênciaVeterinária) - Universidade Federal Rural de Pernambuco, Recife

Almeida ACS (2006) Caracterização dos produtores e propriedadesruraisemtrêsmunicípios do Estado de Pernambuco. Revista Caatinga, Mossoró 19(4):323-332

Ammar H, Bodas R, Ben Younes M, López S (2011) Goat breeding systems in the south of Tunisia (Tataouine). In Economic, social and environmental sustainability in sheep and goat production systems.Zaragoza CIHEAM/ FAO/ CITADGA. Options Méditerranéennes A100, ed. A. Bernués, Boutonnet JP, I. Casasús, M. Chentouf, D. Gabiña, M. Joy, A. López-Francos, P. Morand-Fehr, and F. Pacheco, 283-288.

Apori SO, Osei DY, Rhule SWA, Doku C Oppong-Anane K (2011) Livestock marketing in the coastal savannah zone of Ghana. In: Proceedings of the 17th Biennial conference of the ghana society of animal production, (20th-23rd July, 2011), University of Ghana, Legon, pp 43-45

Arias M, Alonso A (2002) Estudio sobre sistemascaprinosdelnorte de la Provincia de Córdoba, Argentina. Archivos de Zootecnia, Córdoba, v. 51, n. 195, p. 341349,2002

Bembridge (1984) A systems approach study of agricultural development problems in Transkei, Development southern Africa, Vol 1, Nº's 3 and 4 , November 1984.

Benslimane M, Hamimed A, El Zerey W, Khaldi A, Mederbal K (2008) Analyse et suivi du phénomène de la désertification en Algérie du nord VertigO - la revue électronique en sciences de l'environnement, $83 \mathrm{p}$

BNEDER (2006) Identification et cartographie des zones potentielles à l'agriculture en steppe. Alger, Bureau National d'Etude pour le Développement Rural, Etude diachronique du climat et du bioclimat de la steppe algérienne, p 47

Costa VMM, Simões SVD, Riet-Correa F (2011) Controledas parasitoses gastrintestinaisemovinos e caprinos na regiãosemiárida do Nordeste do Brasil. PesquisaVeterináriaBrasileira, Rio de Janeiro 31(1): 65-71

Deleule M (2016) Evolution des systèmes d'élevage dans les steppes du Maghreb: Enjeux et perspectives. Mémoire de master 2 GIEBloTE. Canada: Université de Sherbrooke

Fajemilehin OK, Salako AE (2008) Body measurement characteristics of the West African Dwarf (WAD) Goat in deciduous forest zone of Southwestern Nigeria, African Journal of Biotechnology (18 July, 2008), Vol. 7 (14), 2521-2526

FAOSTAT (2018) Statistics of Food and Agriculture Organization of the United Nations. http://www.fao.org/faostat/fr/\#data/QA. Accessed 2 Mai 2020.

Gaspar P, Escribano M, Mes'ias FJ, Rodriguez de Ledesma A and Pulido F. (2008) Sheep farms in the Spanish rangelands (dehesas): Typologies according to livestock management and economic indicators. Small Ruminant Research 74(2008):52-63

Gnanda BI, Wereme N'Diaye A, Sanon HO, Somda J, Nianogo JA (2016) Rôle et place des caprins dans les ménages au Sahel. Tropicultura 34(1):10-25

Goering HK, Van Soest PJ (1970) Forage fiber analysis: Apparatus, reagents, procedures, and some applications. Agric. Handbook N³79. ARS, USDA, Washington, DC.

Gonçalves AL, Lana RP, Vieira RAM (2008) Avaliação de sistemas de produção de caprinosleiteiros na RegiãoSudeste do Brasil. RevistaBrasileira de Zootecnia, Viçosa, MG 37(2):366-376

González-Recio O, Alenda R (2005) Genetic parameters for female fertility traits and a fertility index in Spanish dairy cattle. J DairySci 88:3282-3289

Gopalakrishnan CA, Lal GMM (1985) Livestock and poultry enterprises for rural development. Vikas Publishing House, New Delhi

Granados-chapatte A, Baret P (2002) Indicateurs de fertilité dans une population de bovins : prise en compte de la qualité des données. Renc Rech Ruminants 9:p153

Guilherme RF, Lima AMC, Alves JRA, da Costa DF, Pinheiro RR, Alves FSF, de Azevedo SS and Alves CJ (2017). Characterization and typology of sheep and goat production systems in the State of Paraíba, a semi-arid region of northeastern Brazil, Semina: CiênciasAgrárias, Londrina, v. 38, n. 4, p. 2163-2178, jul./ago. 2017, DOl: https://doi.org/10.5433/1679-0359.2017v $38 \mathrm{n} 4 \mathrm{p} 2163$

Hadbaoui I (2013) Les parcours steppiques dans la région de M'Sila: Quelle gestion pour quel devenir? Thèse de Magister, Université KasdiMerbah, Ouargla

Hadjiat K (1997) Etat de dégradation des sols en Algérie Rapport expert PNAE. Banque Mondiale 1997:45p

Hagan JK, Apori SO, Bosompem M, Ankobea G and Mawuli A (2012). Morphological Characteristics of Indigenous Goats in the Coastal Savannah and Forest Eco-Zones of Ghana, J. Anim. Sci. Adv. (2012), 2(10): 813-821

Hernández PP, Arroniz JV, Molina HC, Martinez BC, Rivera PD, Ortiz SL (2011) Análisisdescriptivo de los sistemas de produccíon con ovinos en el Estado de Veracruz, México. RevistaCientífica FCV-LUZ, Maracaibo 21(4): 327-334

Holanda Junior FIF, Campos RT (2003) Análisetécnicoeconômica da pecuárialeiteira no município de Quixeramobim - estado do Ceará. RevistaEconômicadoNordeste, Fortaleza 34(4):621-646

Iyiola-Tunji AO, Issa FO (2010) Small ruminant production characteristics by rural farm-families in naerls-adopted and non-adopted villages in northwestern Nigeria. Cont J AnimVet Res 2:18-24 https://www.researchga te.net/publication/283426630

Jaitner J, Sowe J, Secka-Njie E, Dempfle L (2001) Ownership pattern and management practices of small ruminants in the Gambia: implications for a breeding programme. Small Ruminant Res 40:101-108

Kadi SA, Hassani F, Lounas N, Mouhous A (2014) Caractérisation de l'élevage caprin dans la région montagneuse de Kabylie en Algérie. In 8th International Seminar FAO-CIHEAM Network on Sheep and Goats"Technology creation and transfer in small ruminants: Roles of research, development services and farmer associations", Tangier, Morocco, 11 to 13 June 2013. Options Méditerranéennes: Série A. Séminaires Méditerranéens; no. 108, pp 451-456

Kakengi AMV, Mtenga LA, Kimambo AE, Mgheni DM (2000) Performance of two strains of tethered and supplemented small East African goats. In: Proceedings of the 27th scientific conference UCLAS-Dar es Salaam, Tanzania, vol 27, pp 107-125

Kasambula L, Belsham JG, Siegismund HR, Muwanika VB, Ademun-Okurut AR, Masembe C (2012) Serotype identification and VPI coding sequence analysis of foot-and-mouth disease viruses from outbreaks in eastern and northern Uganda in 2008/9. TransboundEmerg Dis 59:323-330. https:// doi.org/10.1111/j.1865-1682.2011.01276

Katongole JBD, Sebolai B, Madimabe MJ (1996) Morphological Characteristics of the Tswana goat. In: Lebbie SHB, Kagwini E (eds) FAO Corporate Document Repository.

Kebede T, Haile A, Dadi H (2011) Smallholder goat breeding and flock management practices in the central rift valley of Ethiopia. Trop Ani Health Prod 44:999-1006

Kosgey IS, Baker RL, Udo HMJ, Van Arendonk JAM (2006) Successes and failures of small ruminant breeding programmes in the tropics: a review. Small Ruminant Res 61:13-28

Laouadi M, Tennah S, Kafidi N, Antoine-Moussiaux N, Moula N (2018) A basic characterization of small-holders' goat production systems in Laghouat area. Algeria Pastoralism 8:24

Laoubi K, Boudi M, Adel M, Yamao M (2011) Exploring family farm development in dryland agricultural areas: a case study of the Laghouat region of Algeria. Afr J Agric Res 6(6):1303-1312. https://doi.org/10.5897/AJAR1 1.070

Lima RGS, Baiardi A (2000) Estratégias de sobrevivência dos pequenoscaprinocultores do semiáridobaiano. SOBER, Riode Janeiro, p 2000

Madani T, Sahraoui H, Benmakhlouf H (2015) L'élevage caprin en Algérie: Systèmes d'élevage, performances et mutations. In Workshop national sur "Valorisation des races locales ovines et caprines à faibles effectifs", INRA "Institut National de la Recherche Agronomique d'Algérie", Ministère de l'Agriculture, du Développement Rural et de la Pèche, Alger, Algérie, 2-3 mars 2015. https://drive.google.com/file/d/OByq7HIXbht6eWGZWdE5 ISm1XQzA/view.

M.A.D.R., (2004) Ministère de l'Agriculture et du Développement Rural, Direction Générale des Forêts Programme d'Action National sur la lutte contre la Désertification, $104 \mathrm{p}$ 
Monte EZ, Teixeira EC (2006) Determinantes da adoção da tecnologia de despolpamento na cafeicultura. Revista de Economia e Sociologia Rural, Rio de Janeiro 44(2):201-217

Morantes M, Rodón Z, Colmenares O, Alvarez LR, Zambrano C (2008). Análisisdescriptivo de los sistemas de producción con ovinos en el Municipio San Genaro de Boconoito (Estado Portuguesa, Venezuela). RevistaCientífica FCV-LUZ, Maracaibo, 18(5):556-561

Moula N, Ait Kaki A, Touazi I, Farnir F, Leroy P, Antoine-Moussiaux N (2017) Goat breeding in the rural district of Chemini (Algeria), Revue « Nature andTechnologie ». B- Sciences AgronomiquesetBiologiques, $n^{\circ}$ 16/Janvier 2017.

Mujica PT, Aguilar C, Vera R, Rivas J, García A (2015) Sheep production systems in the semi-arid zone: changes and simulated bio-economic performances in a case study in Central Chile. Livestock Science, Amsterdam 180(1):209-219

Nassif F, El Amiri B (2011) Promoting multidisciplinary research to improve goat production systems in Morocco. In Economic, social and environmental sustainability in sheep and goat production systems.Zaragoza, CIHEAM/FAO/ CITADGA. Options Méditerranéennes A100, ed. A. Bernués, Boutonnet JP, I. Casasús, M. Chentouf, D. Gabiña, M. Joy, A. López-Francos, P. Morand-Fehr, and F. Pacheco, 299-303.

Nedjraoui D (2006) Algeria Country Pasture/Forage Resource Profiles FAO (2006), $28 \mathrm{p}$

Ogebe PO, Ogwu AO, Mustafa BS, McDowell LR (2000) Effect of tethering feeding system on the performance of West Africa dwarf goats. Livest Res Rural Dev 12:1-7

Ouchene-Khelifi NA, Ouchene N, Meftah A, Da Silva AB, Lafri M (2015) Assessing admixture by multivariate analyses of phenotypic differentiation in the Algerian goat livestock. Trop Anim Health Prod 47(2015):1343-1350

Ouchene-Khelifi NA, Ouchene N, Da Silva A, Lafri M (2018) Multivariate characterization of phenotypic traits of Arabia, the main Algerian goat breed. Livestock Res Rural Dev 30(7):2018

Pala AO (1980) The Joluo Equation, land reform, lower status for women. FAO Review on Agriculture and Development, p 69

Pérez RDG, Gonzáles SFG, Magaña MAM and Lara PEL (2010) Caracterizacióntécnica y socioeconómica de la producciónovina en el estado de Yucatán, México. AgronominaMesoamericana, Alajuela 21(1):131-144

Rancourt M, Fois N, Lavín MP, Tchakérian E, Vallerand F (2006) Mediterranean sheep and goats production: an uncertain future. Small Ruminant Research, Amsterdam 62(3): 167-179

Riet-Correa B, Simões SVD, Pereira Filho JM, Azevedo SS, Melo DB, Batista JA, Miranda Neto EG, Rietcorrea F (2013). Sistemasprodutivos de caprinoculturaleiteira no semiáridoparaibano: caracterização, principaislimitantes e avaliação de estratégias de intervenção. PesquisaVeterináriaBrasileira, Rio de Janeiro 33(3): 345-352
Rodríguez JRG, López SV, Ramírez JLZ, González AB, Bribiesca ER, Rodríguez JDG, Zepeda JSH (2011). Evaluación territorial de los sistemas de producciónovina en la regiónnor-poniente de Tlaxcala. Revista Mexicana de CienciasPecuarias, Cidade do México 2(1): 5368

Rondia P (2006) Aperçu de l'élevage ovin en Afrique du Nord. Filière Ovine et Caprine 18:11-14

Sahli Z (2010) Rapport Final : Projet Agriculture et Rural Durables en régions de montagne-ADRD-M (E-forum Algérie sur la situation et le devenir des montagnes algériennes). Agriculture et Développement Rural Durables. Projet pour des Politiques de Montagne. FAO-CIHEAM. IAM BARI. Janvier 2010. 13 p.

Selvaggi M, Tufarelli V (2012) Caseins of goat and sheep milk: analytical and technological aspects, in Casein: production, uses and health effects. In: Ventimiglia AM, Birkenhäger JM, Nova Science Publishers, New York, 1-25

Selvaggi M, Laudadio V, Dario C, Tufarelli V (2014) Major proteins in goat milk: an updated overview on genetic variability. Mol Biol Rep 41:1035-1048

Sibisi H (1979) Cattle ownership and control sociological observations on some aspects of rural development in Swaziland. Paper no. 1. Ministry of Agriculture and Cooperatives, Mbabane

Tchouamo IR, Tchoumboue J, Lise T (2005) Caractéristiques socio-économiques et techniques de l'élevage de petits ruminants dans la province de l'ouest du Cameroun. Tropicultura 23(4):201-211

Traore A, Tamboura H, Kabore A, Yameogo N, Bayala B and Zare I (2006) Caractérisation morphologique des petits ruminants (ovins et caprins) de race locale "Mossi" au Burkina Faso. Animal GeneticResources Information(AGRI), No. 39,39-50.

Valerio D, García A, Perea J, Acero R and Gómez G (2009). Caracterización social y comercial de los sistemasovinos y caprinos de la RegiónNoroeste de República Dominicana. Interciência, Caracas, 34(9): 637-644

Waiswa C, Picozzi K, Katunguka-Rwakishaya E, Olaho-Mukani W, Musoke AR, Welburn SC (2006) Glossinafuscipes in the trypanosomiasis endemic area of south eastern Uganda. Apparent density, trypanosome infection rates and host feeding preferences. Acta Trop 99:23-20. https://doi. org/10.1016/j.actatropica.2006.06.005

Yandia MC (2012) Analyse du système de commercialisation des caprins dans la ville de Bangui (Centrafrique). Mém. Master Prod. Anim. Dév. Durable, Université Cheikh AntaDiop, Ecole inter-Etats des sciences et de médecine, Dakar, Sénégal, 32 p.

\section{Publisher's Note}

Springer Nature remains neutral with regard to jurisdictional claims in published maps and institutional affiliations.

\section{Submit your manuscript to a SpringerOpen ${ }^{\odot}$ journal and benefit from:}

- Convenient online submission

- Rigorous peer review

- Open access: articles freely available online

- High visibility within the field

- Retaining the copyright to your article

Submit your next manuscript at $\boldsymbol{\nabla}$ springeropen.com 